\title{
PERSONALO KAITOS STABILIZAVIMO GALIMYBĖS LIETUVOS STATYBOS SEKTORIUJE
}

\author{
Asta Stankevičiené ${ }^{1}$, Aušra Liučvaitiene $\dot{e}^{2}$, Agnė Šimelyté $^{3}$ \\ Vilniaus Gedimino technikos universitetas, Sauletekio al. 11, LT-10223 Vilnius, Lietuva \\ El.paštas: ${ }^{1}$ Asta.Stankeviciene@vgtu.lt; ${ }^{2}$ Ausra.Liucvaitiene@vgtu.lt; ${ }^{3}$ Agne.Simelyte@vgtu.lt
}

Iteikta 2009-11-25; priimta 2010-02-22

\begin{abstract}
Santrauka. Personalo kaita neišvengiama bet kurioje organizacijoje. Tačiau dažnai personalo kaitos priežastys bei poveikis organizacijai nèra tinkamai ịvertinamas ar net visai nenagrinèjamas. Tokia situacija susidarè dèl to, kad iki šiol nèra modelio, galinčio įvertinti ir paaiškinti personalo kaitą i̇monèse. Straipsnyje analizuojamos personalo kaitos priežastys ir pagrindiniai veiksniai, lemiantys darbuotojų kaitą, siūlomas personalo kaitą stabilizuojantis devynių veiksnių modelis. Remiantis Lietuvos statybos bendrovių apklausa, nustatytos dažniausios darbuotojų kaitos priežastys. Pagrindiniai siūlomo personalo kaitos stabilizavimo modelio elementai yra: darbo užmokestis, darbo aplinka, pripažinimas, saviraiška, karjeros galimybės, vadovų valdymo stilius ir santykiai su darbdaviais.
\end{abstract}

Reikšminiai žodžiai: personalo kaita, stabilizavimo modelis, darbo vietos keitimas, darbuotojų kaitos priežastys.

\section{THE POSSIBILITIES OF PERSONNEL TURNOVER STABILIZATION IN LITHUANIAN CONSTRUCTION SECTOR}

\author{
Asta Stankevičiené ${ }^{1}$, Aušra Liučvaitiené², Agnė Šimelytė ${ }^{3}$ \\ Vilnius Gediminas Technical University, Sauletekio al. 11, LT-10223 Vilnius, Lithuania \\ E-mails: ${ }^{1}$ Asta.Stankeviciene@vgtu.lt; ${ }^{2}$ Ausra.Liucvaitiene@vgtu.lt; ${ }^{3}$ Agne.Simelyte@vgtu.lt
}

Received 25 November 2009; accepted 22 February 2010

\begin{abstract}
Personnel turnover is inevitable in any organization. However, the reasons of personnel turnover and influence on the organization are often not properly evaluated or even ignored. This situation occurred because the model, which could assess and explain the turnover of personnel in enterprises, has not been developed yet. The article analyses the reasons of personnel turnover as well as the main factors which determine the personnel turnover. In addition, the nine elements model of personnel turnover stabilization is proposed. Meanwhile, the survey of Lithuanian construction companies has helped to identify the most frequent reasons of the change of employees. Further, the major elements of the proposed model of personnel turnover stabilization are analysed: wage, workplace, team spirit, recognition, self-expression, possibilities of career, management style, and relationships with employers.
\end{abstract}

Keywords: personnel turnover, stabilization model, employee turnover, reasons of personnel turnover. 


\section{Ivadas}

Problema. Personalo kaita bet kurioje organizacijoje yra neišvengiama ir turi tiek teigiamą, tiek neigiamą poveikį. Darbuotojų kaita iš dalies naudinga, nes nauji žmonès atneša ị organizaciją naujos patirties ir žinių, naujų technologijų, idejų ir stilių. Organizacija greičiau prisitaiko prie kintančios aplinkos, kai kuriais atvejais kolektyve mažeja konfliktų. Tačiau jeigu darbuotojų kaita yra per didelè, tuomet tai siejasi su įmonès išlaidomis, būtinomis naujiems darbuotojams verbuoti, juos apmokyti. Apmokant naują darbuotoją, sumažèja gamybos apimtis, o pavaduojančiam darbuotojui, kol nerasta naujo, reikia mokèti priedą. Be kita ko, naujokai daro klaidu, suyra darbo grupès ir pakenkiama darbo moralei. Personalo kaita ypač veikia organizacijos produktyvumą. Nuostoliai atsiranda išèjus darbuotojui ir i jo vietą prièmus kitą: nuo seno čia dirbantys turi supažindinti su darbo esme ir apmokyti naujokus. Apklausu užsienio šalyse duomenimis, nustatyta, kad prižiūrintis darbuotojas naujojo darbuotojo "globai“ per tris mėnesius praranda apie $28 \%$ savo darbo laiko. Naujai priimti darbuotojai tik maždaug po 13,6 savaičiu pradeda produktyviai dirbti. Naujai priimtas darbuotojas mokymų metu tik iki $53 \%$ viso darbo laiko sugeba savarankiškai dirbti (Renggli, Ziorjen 2005). Todèl kiekviena organizacija turi imtis priemonių personalo kaitai mažinti, kad šios kaitos lygis netaptų per didelis.

Personalo kaita ryški Lietuvos statybos sektoriuje. Nors šiuo metu nekvalifikuotų darbininkų pasiūla rinkoje labai viršija paklausą, tačiau didžiausia personalo kaita statybų sektoriuje susidaro būtent žemiausios kvalifikacijos darbuotojų sluoksnyje, o kvalifikuotų specialistų dažnai trūksta. Pažymètina, kad sezoniniai darbai Lietuvos statybų sektoriuje glaudžiai siejasi su personalo kaita. Daugumai statybos įmonių didinant savo darbų apimtị šiltuoju metu laiku, atsiranda daugiau galimybių ir nekvalifikuotiems darbininkams ịsidarbinti statybos sektoriuje. Toks reiškinys paaiškina teigiamą sezoninių darbininkų kaitos poveikị organizacijos veiklai. Tačiau dažna personalo kaita blogina atliekamų statybos darbų kokybę, rodo menką organizacijos kultūrą, sukelia papildomų išlaidų ieškant, įdarbinant, mokant naujus statybos darbuotojus. Todèl naudinga išanalizuoti Lietuvos statybos įmonių darbuotojų kaitos priežastis, kaitos rodiklius bei parengti modelį, leisiantị stabilizuoti personalo kaitą minètame sektoriuje.

Darbo tikslas. Remiantis teoriniais ir praktiniais tyrimų rezultatais, parengti personalo kaitos stabilizavimo modeli Lietuvos statybos sektoriuje.

Tyrimo metodai. Lietuvos ir užsienio autorių teorinių koncepcijų apžvalga personalo kaitos klausimais, statistinių rodiklių analizè ir anketinè apklausa.

\section{Personalo kaitos stabilizavimo teoriniu koncepcijų apžvalga}

Vienas pirmụjų autorių, nagrinejjusių šią problema, Price (1977) išskyrẻ savanorišką personalo kaitą, kaip asmenini judejjimą socialine sistema, inicijuotą pačiu individų. Tačiau toks požiūris - gana siauras, pabrèžiantis išẻjimą iš organizacijos tik darbuotoju iniciatyva. Reikia pažymèti, kad kitų autorių (Vandenberghe 1999; Carmeli, Weisberg 2006) nuomone, kaita - tai „natūralūs“ išèjimai iš darbo vietos: studijų pradejjimas, mirtis, neigalumo atsiradimas, išèjimas ì pensiją, persikvalifikavimas ar pašaukimas ị kariuomenę. Personalo kaita taip pat suprantama kaip darbuotojų darbo vietos keitimas geografiškai arba organizacijos viduje (t. y. perkèlimas, paaukštinimas, pažeminimas ir atleidimas) (Bakanauskienė 2002), arba išorèje (išèjimai iš darbo vietos, priklausantys nuo natūralių priežasčių, išejimai iš darbo vietos, priklausantys nuo įmonès, išèjimai iš darbo vietos, priklausantys nuo darbo sutarties) (Stübinger 2003). Šiai nuomonei pritarè ir Abbasi bei Hollman (2000), kurie teigé, kad personalo kaita - darbuotoju „sukimasis“ darbo rinkoje tarp organizacijų, darbų, verslo bei pramonès šakos/šalies užimtumo ir nedarbo (Martinkus et al. 2009).

Personalo kaitos sampratą apibrèžti ir personalo kaitos priežastis nustatyti padeda darbuotojų požiūrio ị darbą ir svarbiausių interesų sąsajų nustatymas. Ši reiškinị galima paaiškinti tuo, kad individas išskiria savo požiūrị i darbą ir poilsị ịvairiais aspektais. Tyrëjų Čiutienès ir Adamonienès (2009) atlikta personalo kaitos priežasčių analizè parodė pagrindines požiūrio ị darbą kryptis:

- gyvenu, kad dirbčiau;

- dirbu, kad galečiau gyventi;

- darbas svarbus, tačiau neturi trukdyti asmeniniam gyvenimui.

Kvalifikacijos tobulinimas, žinių ir igūdžių taikymas kūrybinèms užduotims iggyvendinti, socialinis pripažinimas bei didesnis darbo užmokestis išlaikytų darbuotojus, kurie aukoja asmenini gyvenimą dèl darbo. Tačiau didesnès darbo užmokesčio galimybės neturètų būti tokios svarbios tiems, kurie dirba tik tam, kad gyventų. Darbuotojams, kurie siekia darbo ir asmeninio gyvenimo balanso, reikètų užtikrinti socialinio pripažinimo, savęs realizavimo galimybes bei gerą psichologinị klimatą.

Tyrejjai Čiutienè, Sakalas ir Neverauskas (2006) pabrèžia skirtingus vyrų ir moterų darbo interesus, o tai ir lemia skirtingą jų kaitą įmonėse. Anot jų, moterys labiau nei vyrai suinteresuotos parodyti profesinius gebejjimus, jausti socialini pripažinimą bei matyti savo indèlį siekiant įmonès tikslų. Skirtingai negu vyrai, moterys teikia pirmenybę dirbti lanksčiu grafiku. Beje, Lietuvos (Martinkus et al. 2002; Čiutienè et al. 2006; Bagdanavičius, Jodkienè 2008; Čiutienè, Adomonienè 2009) bei užsienio autoriai (Gaether 1999; Abbasi, Hollman 2000; Trevor 2001; Winterton 2004; 
Carmeli, Weisberg 2006) pažymi, kad personalo kaitos priežastys yra dvejopos: asmeninès (natūralios/savanoriškos), imonès viduje (kontroliuojamos) bei išorèje (mažai kontroliuojamos) kylančios priežastys (1 lentelè). Kai kurių tyrèjų nuomonei, kad personalo kaita apibūdinama kaip rodiklis, kuris padeda nustatyti darbuotojų, ateinančių ị organizaciją ir išeinančių iš jos, santyki (Griffeth et al. 2000; Jewell 2002), galima pritarti, taip pat ir teigti, kad šiuos rodiklius tikslinga nustatyti.

Apibendrinant nuomonių šiuo klausimu įvairovę, galima išskirti vyraujančius du požiūrius ì personalo kaitą: darbo vietos keitimas arba rodiklis, rodantis ateinančių ir išeinančių iš organizacijos darbuotojų santykį. Straipsnyje autorès personalo kaitą apibūdina kaip darbo vietos keitimą (paliekant organizaciją).
Atskirais atvejais personalo kaita auga nežinant apie problemas, kylančias įmonės viduje, ar nekreipiant $\underset{i}{j}$ jas dèmesio. Jeigu darbo vietą keičia jauni, gabūs ir profesionalūs darbuotojai, galima manyti, kad pagrindinè to priežastis - tiesioginès ar netiesioginès motyvacijos trūkumas. Turi reikšmès ir personalo kaitos didejjimui. Ilgalaikis investavimas ị darbuotojus: įvairūs mokymai, kurie sietini su darbuotojų karjeros galimybėmis, suteikia stimulą dirbti toje pačioje įmonèje. Skirstant darbuotojus ị komandas, darbo grupes, ypač svarbus psichologinis veiksnys (Žukauskas, Vveinhardt 2009). Taigi vadovautis vien nusistovejusiais samdos principais įmonei dažnai būna nenaudinga ir nauji darbuotojai dèl darbinio nepalankaus klimato įmonę palieka. Naujai priimamų ar jau esamų darbuotojų požiūris ị darbą, poilsị ir jų interesų sąryšis, suteikia galimybę

1 lentelè. Personalo kaitos padariniai (remiantis Gaether 1999; Abbasi, Hollman 2000; Trevor 2001; Winterton 2004; Carmeli, Weisberg 2006; Kazlauskienè, Rinkevičius 2006)

Table 1. The effects of personnel turnover (according to Gaether 1999; Abbasi, Hollman 2000; Trevor 2001; Winterton 2004; Carmeli, Weisberg 2006; Kazlauskienè, Rinkevičius 2006)

\begin{tabular}{|c|c|c|}
\hline \multicolumn{3}{|c|}{ Personalo kaitos priežastys } \\
\hline Veiksnys & Padariniai & Personalo kaitos stabilizavimo priemonès \\
\hline \multicolumn{3}{|c|}{ İmonės viduje kylančios priežastys } \\
\hline $\begin{array}{l}\text { Gabiausi ir profesionaliausi } \\
\text { darbuotojai - mobiliausi } \\
\text { ir linkę keisti darbo vietas } \\
\text { dažniau }\end{array}$ & $\begin{array}{l}\text { Darbuotojų netekimas neigiamai veikia } \\
\text { darbo kokybę, teikiamas paslaugas, } \\
\text { inovacijas, klientų poreikių patenkinimą. }\end{array}$ & $\begin{array}{l}\text { Ilgalaikis investavimas ị darbuotojus: } \\
\text { sukuriant motyvavimo programas ir nuolatinị } \\
\text { mokymąsi. }\end{array}$ \\
\hline Nusistovėjusi samdos tvarka & $\begin{array}{l}\text { Netinkama darbuotojų atranka ir samda } \\
\text { lemia neproporcingai didelę kaitą itmonèje } \\
\text { bei aukštas darbuotojo išèjimo sąnaudas. }\end{array}$ & $\begin{array}{l}\text { Samdos kriterijai turi atitikti ne tik įmonės } \\
\text { poreikius, bet ir turi būti suderinti su įmonès } \\
\text { kultūra bei strategija. }\end{array}$ \\
\hline Valdymo stilius & $\begin{array}{l}\text { Trumparegiai vadovai parenka } \\
\text { neproporcingą kvalifikuotų darbuotojų } \\
\text { skaičių, atrenka neatsižvelgdami í } \\
\text { „šiandienos“ poreikius, nes buvo } \\
\text { užtikrinti „vakarykščia“ diena, bet ne } \\
\text { ateitimi. }\end{array}$ & $\begin{array}{l}\text { Valdymo stiliaus netinkamumo pripažinimas } \\
\text { leistų išlaikyti darbuotojus, darbo jègos } \\
\text { pasikeitimo dinamikos stebejimas sukurtų } \\
\text { galimybę diversifikuoti darbus, sukuriant } \\
\text { motyvacijos sistemą ir taip išlaikant lojalius } \\
\text { darbuotojus. }\end{array}$ \\
\hline Pripažinimo trūkumas & $\begin{array}{l}\text { Asmeninio ir komandinio pripažinimo } \\
\text { trūkumas lemia darbuotojų } \\
\text { neproduktyvumą atliekant darbus. }\end{array}$ & $\begin{array}{l}\text { Darbuotojams karjeros galimybių suteikimas, } \\
\text { darbo užmokesčio sistemos sukūrimas: } \\
\text { pastovaus ir motyvacinio atlyginimo } \\
\text { mokejjimas, galimybè realizuoti save, } \\
\text { dalyvavimas mokymosi ir plètros programose } \\
\text { keltų darbuotojų darbo produktyvumą ir } \\
\text { kvalifikaciją. }\end{array}$ \\
\hline $\begin{array}{l}\text { Konkurencinès } \\
\text { kompensavimo sistemos } \\
\text { nebuvimas }\end{array}$ & $\begin{array}{l}\text { Lemiamas veiksnys siekiant igyvendinti } \\
\text { strateginius tikslus, susietus su } \\
\text { žmogiškaisiais ištekliais, t. y. netinkamai } \\
\text { sukurta darbo užmokesčio sistema gali } \\
\text { didinti darbuotojų kaitą. }\end{array}$ & $\begin{array}{l}\text { Darbo užmokesčio sistemos sukūrimas, } \\
\text { siekiant ịvertinti kiekvieną darbuotoją už } \\
\text { jo pasiekimus atskirai, motyvuojant juos } \\
\text { tarpusavyje varžytis, kai įmonè sau užsitikrina } \\
\text { ne tik lojalius darbuotojus, bet ir didesnị pelną. }\end{array}$ \\
\hline Nepalankios darbo sąlygos & $\begin{array}{l}\text { Žema įmonès vidinė kultūra, } \\
\text { lojalumo nuolatinis mažejimas, darbo } \\
\text { produktyvumo mažejimas, žemas ryšiu su } \\
\text { klientais palaikymas ir stresas tiems, kurie } \\
\text { dirba. }\end{array}$ & $\begin{array}{l}\text { Atitinkamų personalo kaitos mažinimo } \\
\text { programų taikymas: ryšių su darbuotojais } \\
\text { gerinimas, psichologinio klimato lygio } \\
\text { kèlimas, darbo saugos programos } \\
\text { igyvendinimas ir laikymasis. }\end{array}$ \\
\hline
\end{tabular}


1 lenteles pabaiga

\begin{tabular}{|c|c|c|}
\hline \multicolumn{3}{|c|}{ Personalo kaitos priežastys } \\
\hline Veiksnys & Padariniai & Personalo kaitos stabilizavimo priemonès \\
\hline \multicolumn{3}{|c|}{ İmonės išorèje kylančios priežastys } \\
\hline Darbo rinkos padetis & \multirow{5}{*}{$\begin{array}{l}\text { Darbuotojų netekimas neigiamai veikia } \\
\text { darbo kokybę, teikiamas paslaugas, } \\
\text { inovacijas, klientų pasitenkinimą. }\end{array}$} & $\begin{array}{l}\text { Imonè negali daryti poveikio darbo rinkos } \\
\text { padéčiai }\end{array}$ \\
\hline Susisiekimo galimybès & & Imonès automobilio darbuotojui suteikimas \\
\hline Infrastruktūra & & Imonè negali veikti infrastruktūros. \\
\hline $\begin{array}{l}\text { Geresnès sąlygos kitose } \\
\text { itmonèse }\end{array}$ & & $\begin{array}{l}\text { Darbo užmokesčio sistemos sukūrimas, } \\
\text { siekiant ịvertinti kiekvieną darbuotoją už } \\
\text { jo pasiekimus atskirai, motyvuojant juos } \\
\text { tarpusavyje varžytis, kai ịmone sau užsitikrina } \\
\text { ne tik lojalius darbuotojus, bet ir daugiau pelno }\end{array}$ \\
\hline Ekonominè padètis & & $\begin{array}{l}\text { Imonè negali daryti poveikio ekonominei } \\
\text { padéčiai }\end{array}$ \\
\hline \multicolumn{3}{|c|}{ Asmeninės priežastys } \\
\hline $\begin{array}{l}\text { Amžius; profesijos } \\
\text { pakeitimas; asmeninės } \\
\text { veiklos pradžia; liga; } \\
\text { kvalifikacijos kèlimas; } \\
\text { gyvenamosios vietos } \\
\text { pakeitimas; šeiminès padėties } \\
\text { pasikeitimas }\end{array}$ & $\begin{array}{l}\text { Darbuotojų netekimas neigiamai veikia } \\
\text { darbo kokybę, teikiamas paslaugas, } \\
\text { inovacijas, klientų pasitenkinimą. }\end{array}$ & $\begin{array}{l}\text { İmonè negali daryti ịtakos „natūraliems } \\
\text { išèjimams“ iš įmonès }\end{array}$ \\
\hline
\end{tabular}

geriau pažinti darbuotoją kaip individą. Darbuotojų pažinimas formuoja prielaidas psichologiniam suderinamumui komandoje pasiekti, nustatyti darbo užmokesčio sistemą ir darbo grafiką (Griffeth et al. 2000).

Išsiaiškinus personalo kaitos priežastis, tikslinga jas išanalizuoti ir kiek įmanoma sumažinti jų poveikį. Todèl kitas etapas - numatyti strategijas, mažinančias per didelę darbuotojų kaitą. Jos apima šias priemones:

- gerinti darbuotojų atranką, orientavimą ir mokymą;

- garantuoti darbuotojams darbo krūvị pagal einamas pareigas bei darbo laiką;

- gerinti darbo sąlygas;

- skatinti sutelktumą ir kelti grupių moralę;

- darbą turtinti, kaitalioti ir išplèsti užduotis;

- numatyti paaukštinimo galimybes;

- peržiūrèti darbo užmokesčio struktūrą (Renggli, Ziorjen 2005).

Tikètina, kad nepakanka vien nustatyti darbuotojų kaitos priežasčių. Svarbu darbuotojų kaitą îvertinti kiekybiškai, t. y. skaičiuojant santykinius rodiklius:

- prièmimo intensyvumą, apskaičiuojamą kaip priimtų i darbą darbuotojų ir sąrašo darbuotojų vidutinio skaičiaus santykis (Martinkus et al. 2002);.

- atleidimo intensyvumą, apskaičiuojamą kaip atleistų darbuotojų ir sąrašo darbuotojų vidutinio skaičiaus santykis (Martinkus et al. 2002);
- stabilumo indeksą, apskaičiuojamą kaip darbuotojų, dirbančių ilgiau nei metus, skaičiaus ir bendro darbuotojų, ịdarbintų per metus, skaičiaus santykis (Martinkus et al. 2002);

- personalo kaitos intensyvumą, rodantị dèl darbo drausmès pažeidimų atleistų darbuotojų bei atleistų savo noru darbuotojų skaičiaus indeksą (Čiutienè et al. 2006).

Straipsnyje nagrinejjamos personalo kaitos priežastys sudaro galimybę ịvertinti šią kaitą veikiančius bei lemiančius elementus ir, atsižvelgiant $i$ tai, suformuoti personalo kaitos stabilizavimo modelį. 2 lenteleje pateikiami ịvairių autorių išnagrinèti personalo kaitos stabilumą užtikrinantys elementai bei jų poveikio kaitai įvertinamas. Personalo kaitos stabilumą užtikrinantys elementai ịvertinami pozityviu ir (arba) negatyviu poveikiu darbuotojui. Išanalizavus ivvairių autorių pateiktus personalo kaitos modelius, pastebèta, kad minèti autoriai išskiria panašius elementus, tačiau nepateikia bendro modelio, kuris apimtų visus personalo kaitą lemiančius veiksnius. Apibendrinusios ịvairių autorių nagrinèjamus personalo kaitą lemiančius elementus, straipsnio autorès suformavo personalo kaitos stabilizavimo modelị (1 pav.).

Naudojantis suformuotu modeliu, atliktas personalo kaitos tyrimas Lietuvos statybos sektoriaus įmonėse, kurio rezultatai, identifikuojant personalo kaitos priežastis, leidžia numatyti kaitos tendencijas šiame sektoriuje. 
2 lentelè. Personalo stabilumą užtikrinantys elementai (remiantis Kim, Mauborgne 1996; Vandenberghe 1999; Gaertner 1999; Trevor 2001; Jiang, Klein 2002; Morrell et al. 2004; Winterton 2004; Šukys et al. 2004; Lee, Rwirgema 2005; Biwas 2007; Startiené, Remeikienè 2009; Žukauskas, Vveinhardt 2009)

Table 2. The elements ensuring personnel stability (according to Kim 1996; Vandenberghe 1999; Gaertner 2000; Trevor 2001; Jiang, Klein 2002; Morrell et al. 2004; Winterton 2004; Šukys et al. 2004; Lee, Rwirgema 2005; Biwas 2007; Startienė, Remeikienè 2009; Žukauskas, Vveinhardt 2009)

\begin{tabular}{|c|c|c|}
\hline Modelio elementai & Elementų poveikis kaitai & Autorius \\
\hline Organizacijos kultūra & Pozityvus & Vandenberghe (1999) \\
\hline Darbo užmokestis & Pozityvus & Kim (1996), Gaertner (2000) \\
\hline Karjeros galimybė & Pozityvus & Kim (1996), Gaertner (2000), Morrell et al. (2004) \\
\hline Kolegų palaikymas & Pozityvus & Kim (1996), Gaertner (2000) \\
\hline Vadovų palaikymas & Pozityvus & Kim (1996), Gaertner (2000) \\
\hline Psichologinis klimatas & Pozityvus & Biwas (2007), ), Žukauskas, Vveinhardt (2009) \\
\hline Vadovų kompetencija & Pozityvus & Jiang, Klein (2002) \\
\hline Darbo krūvis & Negatyvus & Kim (1996), Gaertner (2000) \\
\hline Darbo sauga & Pozityvus & Jiang, Klein (2002), ), Šukys et al. (2004) \\
\hline Konfliktai & Negatyvus & Kim (1996), Gaertner (2000) \\
\hline Pareigybės neapibrèžtumas & Negatyvus & Kim (1996), Gaertner (2000) \\
\hline Autonomija & Pozityvus & Kim (1996), Gaertner (2000), Jiang, Klein (2002) \\
\hline Rutina & Negatyvus & Kim (1996), Gaertner (2000) \\
\hline Lūkesčių neatitikimas & Negatyvus & Morrell et al. (2004) \\
\hline Pasitenkinimas darbu & Pozityvus & Trevor (2001), Winterton (2004), Biwas (2007) \\
\hline Lojalumas organizacijai & Pozityvus & Winterton (2004), Willy (2007) \\
\hline Vidinė darbuotojo motyvacija & Pozityvus & Lee, Rwirgema (2005), Biwas (2007) \\
\hline Gyvenimo būdas & Pozityvus/Negatyvus & Jiang, Klein (2002) \\
\hline Kapitalo judèjimas & Pozityvus/Negatyvus & Trevor (2001) \\
\hline Geografinès vietovès saugumas & Pozityvus & Jiang, Klein (2002), ), Startienè, Remeikienė (2009) \\
\hline Laisvų darbo vietų skaičius rinkoje & Pozityvus/Negatyvus & Trevor (2001), Winterton (2004) \\
\hline Verslo sektorius & Pozityvus/Negatyvus & Jiang, Klein (2002) \\
\hline
\end{tabular}

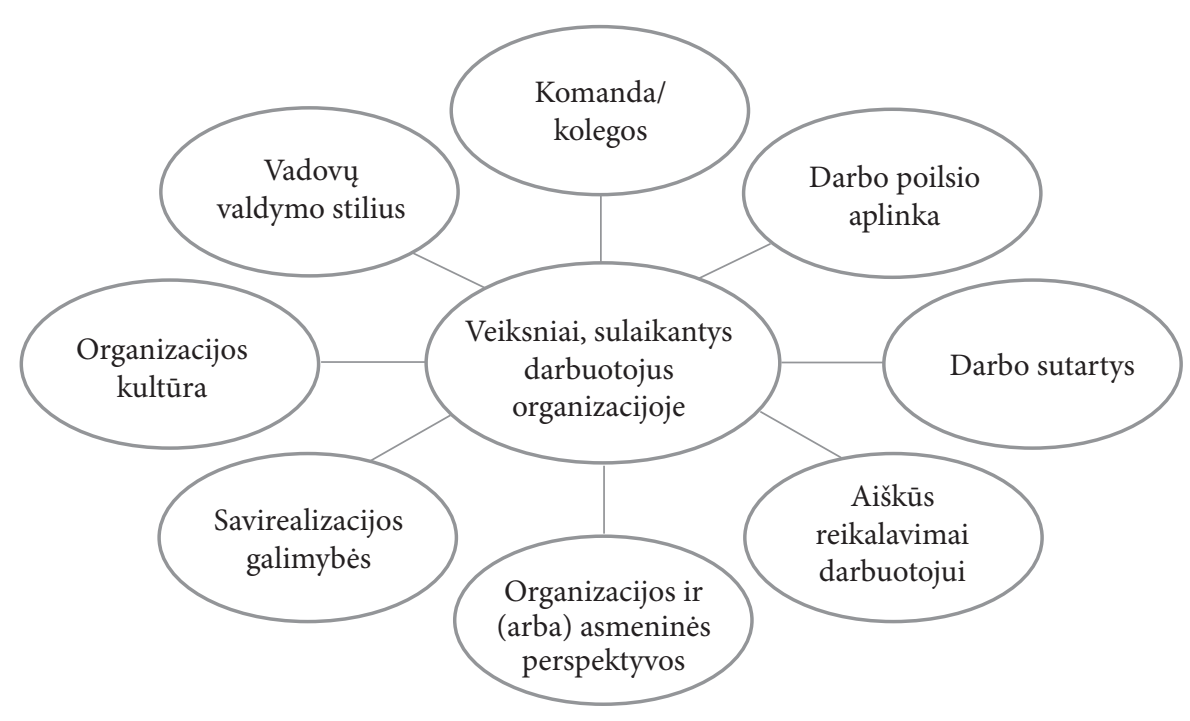

1 pav. Personalo kaitos stabilumą užtikrinantis modelis (remiantis Kim 1996; Gaertner 2000; Trevor 2001; Jiang, Klein 2002; Morrell et al. 2004; Winterton 2004; Lee, Rwirgema 2005; Biwas 2007)

Fig. 1. The elements ensuring the stability of personnel turnover (according to Kim 1996; Gaertner 2000; Trevor 2001; Jiang, Klein 2002; Morrell et al. 2004; Winterton 2004; Lee, Rwirgema 2005; Biwas 2007) 


\section{Personalo kaitos tyrimo Lietuvos statybu sektoriuje metodika ir rezultatai}

Lietuvos statistikos departamento duomenimis, 20042008 m. personalo kaitos koeficiento kitimui statybų sektoriuje turèjo ittakos ekonomikos augimo ir nekilnojamojo turto paklausos pokyčiai. Atsižvelgiant į minètas priežastis, apskaičiuotas koeficientas - mažiausias 2004-2006 m., atitinkamai didžiausia kaita pastebima 2007-2008 m. Staigus darbo kaitos koeficiento nuosmukis (iki-5,2) 2008 m. lèmé pridètinès vertès bei užimtųjų šiame sektoriuje mažèjimą (2 pav.).

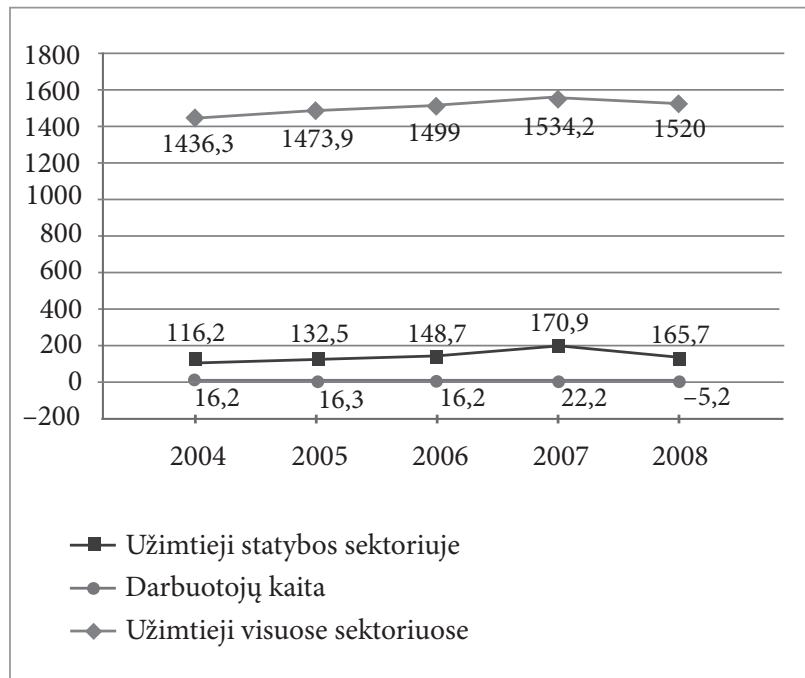

2 pav. Personalo kaitos koeficiento kitimas Lietuvos statybos sektoriuje 2004-2008 m.

Fig. 2. The trend of personnel turnover ratio in Lithuanian Construction Sector (2004-2006)

Siekiant nustatyti personalo kaitos priežastis, $2008 \mathrm{~m}$. balandžio $15 \mathrm{~d}$. - gegužės $10 \mathrm{~d}$. atlikta 83 Lietuvos statybos imonių apklausa. Joje dalyvavo i̇monių personalo skyrių vadovai bei vidurinès ir aukščiausios grandies vadovai. Taip pat apklausti anksčiau tose įmonèse dirbę darbuotojai. Tyrimo tikslas - nustatyti personalo kaitos priežastis Lietuvos statybos imonèse. Tyrimo metodas - anketinè apklausa. Tyrimo imtis - apklaustos 83 Lietuvos statybos i̇monès: 50 smulkių, 28 vidutinès ir 5 didelès įmonès. Iš viso apklausti 92 darbuotojai bei 170 vadovų.

Atlikus Lietuvos statybos įmonių apklausą išryškejjo pagrindinès kaitos tendencijos:

- darbuotojai atleidžiami iš statybos įmonių dažniausiai dèl darbo drausmès pažeidimų $(99 \%)$ ir termino pasibaigimo (34\%);

- darbdaviai išskiria pagrindines asmenines priežastis, dèl kurių darbuotojai palieka įmonę: mažas darbo užmokestis (53\%), gyvenamosios vietos pakeitimas (40 \%). Retesnès priežastys yra organizacijos valdymo stilius (28 \%), ligos (27\%), amžius (24\%), nepasitenkinimas darbu (23\%).

Svarbiausi veiksniai, lemiantys personalo kaitą -materialiniai (82 \%) bei darbo aplinka (58 \%), mažiau svarbūs savęs realizavimas, pripažinimas, karjera, atsakomybè, bendradarbiavimas, darbo turinys ir laimejjimai.

\section{Personalo kaitos mažinimo modelis Lietuvos statybų sektoriuje}

Vykdant apklausą atskleista, kad paprastai personalo kaitą lemia: darbo užmokestis, darbo aplinka, darbo turinys, komandinis darbas, pripažinimas, savęs realizavimas, ateities perspektyvos (karjeros galimybès), vadovų valdymo stilius bei santykiai su vadovais. Minèti kriterijai tarpusavyje glaudžiai susiję ir formuojantys darbuotojo apsisprendimą dirbti įmonejje ilgesnį laiką. Susisteminus tyrimo rezultatus ir pritaikius autorių sukurtą personalo kaitos modelį, siūlomas devynių kriterijų personalo kaitos stabilumą užtikrinantis modelis (3 pav.).



3 pav. Devynių kriterijų modelis, stabilizuojantis personalo kaitą

Fig. 3. The nine criterions' model of personnel turnover stabilization

Atliktas tyrimas nors ir patvirtina materialinių veiksnių svarbą renkantis kitą i̇monę ar pasiliekant toje pačioje, sprendimas palikti įmonę priimamas atsižvelgiant ir ị kitus veiksnius. Nagrinėjant personalo kaitos problemas, tikslinga atsigręžti ir ị darbuotojo psichologinę būseną, lūkesčius bei savęs realizavimą. Daugeliu atvejų darbuotojai išeina iš darbo ir išvyksta į užsienị. To priežastis - ne tik materialinè nauda, bet ir siekis patenkinti savo kompetencijos poreikius, juo labiau kad jie neabejoja lengvu savo profesinès kompetencijos perkèlimu ị kitos šalies sistemą (Bagdanavičius, Jodkonienė 2009). Pavyzdžiui, statybų sektoriuje dirbantis darbuotojas, turintis tinkamą kvalifikaciją ir galintis realizuoti turimas žinias bei igyti naujų, mažiau suinteresuotas keisti darbo vietą.

Komandinis darbas taip pat yra svarbus kriterijus, norint išlaikyti darbuotoją įmonèje. Sèkmingai dirbančio- 
je komandoje, esant geram tarpusavio sąryšiui ir skirtumų suderinamumui, sukuriama pridètinè vertè, kuri atsiranda sujungus skirtingas žinias ir gebejjimus (Žukauskas, Vveinhardt 2009). Darbui palanki aplinka šiandien suprantama kaip saugi, sveika ir užtikrinanti darbuotojo orumą. Darbo aplinką statybos aikšteleje lemia statybos specifika. Todèl, norint užtikrinti gerą darbo aplinką, svarbu gerinti techninę bazę, diegti naujesnes technologijas, gerinti darbo sąlygas (Šukys et al. 2004).

Kadangi darbuotojų kaitai turi reikšmès vadovo bei kolegų elgesys, vadovas turètų pasirinkti optimalų valdymo stilių, kad darbuotojai jaustųsi gerbiami bei vertinami. Kilusius konfliktus tarp darbuotojų būtina spręsti greitai ir efektyviai.

Pateiktame personalo kaitą Lietuvos statybos sektoriuje mažinančiame modelyje atsižvelgiama ị svarbiausius veiksnius, kurie tiesiogiai lemia darbuotojo apsisprendimą palikti įmonę, mažindami personalo kaitą.

\section{Išvados}

1. Apibendrinant personalo kaitos sampratos teoriniu koncepcijų ịvairovę galima teigti, kad vyrauja du požiūriai ì personalo kaitą: darbo vietos keitimas arba rodiklis, rodantis ateinančių ir išeinančiu iš organizacijos darbuotojų santyki.

2. Siekiant išsiaiškinti personalo kaitos priežastis įmonèje, būtina laiku nustatyti sąsają tarp darbuotojo požiūrio i darbą ir jo interesus, kurie leidžia tinkamai paskirstyti darbo užduotis, suformuoti komandas, nustatyti darbo užmokesčio sistemą bei darbo grafiką.

3. Personalo kaitos priežastys ìvairių autorių požiūriu išsiskiria ị dvi grupes. Vieni teigia, kad darbuotojai dažniausiai palieka įmonę dèl asmeninių (natūralios/savanoriškos) priežasčių, o kiti labiau išskiria ịmonès viduje (kontroliuojamos) ir (arba) išorèje (mažai kontroliuojamos) susiformavusias priežastis.

4. Darbuotojų kaita įmonėse įvertinama šiais santykiniais rodikliais: priemimo bei atleidimo intensyvumu, stabilumo indeksu bei personalo kaitos intensyvumu. Rodiklių yra ir daugiau, tačiau dauguma iš jų negali būti taikomi dèl praktinès naudos i̇monei nebuvimo.

5. Personalo kaitą stabilizuojančių modelių pagrindiniai elementai yra: komanda, vadovų valdymo stilius, poilsio patalpos, karjera, reikalavimai, darbo užduotys, organizacijos kultūra bei darbo sutartys.

6. Remiantis Lietuvos statybos ịmonių statistiniais duomenimis, pastebima, kad didžiausia kaita buvo 20072008 m., o mažiausia - 2004-2006 m. Nustatyta, kad 2008 m. buvo neigiamas kaitos koeficientas, o tai lèmé mažesnę pridètinę vertę bei šiame sektoriuje užimtų darbuotojų mažèimą.
7. Lietuvos statybos įmonių apklausa atskleidè tendenciją, kad dažniausia priežastis, dèl kurios darbuotojai palieka ịmonę, yra mažas darbo užmokestis. Antroji pagal svarbumą priežastis - gyvenamosios vietos pakeitimas. Statybos įmonèse darbuotojai dažniausiai atleidžiami dèl darbo drausmès pažeidimų, t. y. pravaikštų ir alkoholio vartojimo darbo vietoje. Lyginamosios analizès metu nustatyta, kad personalo kaitos priežastys ịvairaus dydžio statybos įmonèse yra tos pačios, tik skiriasi jų svarba.

8. Parengtas devynių kriterijų personalo kaitos stabilizavimo modelis, kurio pagrindiniai elementai - darbo užmokestis, darbo aplinka, vadovų valdymo stilius ir santykiai su vadovais. Modelị taikant praktiškai, būtų imanoma stabilizuoti personalo kaitą Lietuvos statybos imonèse, nes modelio veiksniai tiesiogiai veiktų personalo kaitos priežastis bei neleistų joms atsirasti.

\section{Literatūra}

Abbasi, M. S; Hollman, K. W. 2000. Turnover: the real bottom line, Public Personnel Management 29 (3): 333-342.

Bagdanavičius, J; Jodkiene, Z. 2008. Brain drain from Lithuania: the attitude of civil servants, Inzinerine Ekonomika - Engineering Economics (2): 55-60.

Bakanauskienè, I. 2002. Personalo valdymas: metodinè priemonè. Kaunas: VDU leidykla.

Biwas, S. 2007. Job satisfaction and job involvement as mediators of the relationship between psychological climate and turnover intention, South Asian Journal Of Management 16(1): 27-43.

Carmeli, A; Weisberg, J. 2006. Exploring turnover intentions among three professional groups of employees, Human Resource Development International 9(2): 191-206. doi:10.1080/13678860600616305

Čiutienè, R; Adomonienè, R. 2009. Interaction between employee's interests and attitude towards work as well as influence when forming career, Inzinerine Ekonomika - Engineering Economics (2): 48-55.

Čiutienè, R; Sakalas, A; Neverauskas, B. 2006. Influence of personnel interests on formation of modern career, Inzinerine Ekonomika - Engineering Economics (5): 99-106.

Gaether, S. 1999. Structural determinants of job saticfaction and organizational commitment in turnover models, Human Resource Management Review 9(4): 479-493. doi:10.1016/S1053-4822(99)00030-3

Griffeth, R. W.; Hom, P. W.; Gaertner, S. 2000. A Meta-analysis of antecedents and correlates of employee turnover, Journal of Management 26(3): 463-488. doi:10.1177/014920630002600305

Jiang, J. J; Klein, G .2002. A Discrepancy model of information system personnel turnover, Journal of Management Information Systems 19(2): 249-272.

Jewell, B. R. 2002. Integruotos verslo studijos. Vilnius: The Baltic Press. 487 p. 
Kazlauskienè, A; Rinkevičius, L. 2006. The role of social capital in the highly-skilled migration from Lithuania, Inzinerine Ekonomika - Engineering Economics (4): 69-75.

Kim, W. C.; Mauborgne, R. A. 1996. Procedural justice and managers' in-role and extra-role behavior: the case of the multinational, Management Science 42(4): 499-515. doi:10.1287/mnsc.42.4.499

Lee, G. J.; Rwirgema, H. 2005. Mobley revisited: dynamism in the process of employee turnover, International Journal of Human Resource Management 16(9): 1671-1690. doi:10.1080/09585190500239333

Martinkus, B.; Stoškus, S; Beržinskienè, D. 2009. Changes of employment through the segmentation of labour market in the Baltic States, Inzinerine Ekonomika - Engineering Economics (3): 41-48.

Martinkus, B.; Žilinskas, V.; Žičkienè, S. 2002. Imonès ekonomika. Šiauliai: Šiaulių universiteto leidykla.

Morrell, K.; Loan-Clarke, J.; Wilkinson, A . 2004. The role of shocks in employee turnover, British Journal of Management, 15: 335-349. doi:10.1111/j.1467-8551.2004.00423.x

Price, J. L. 1977. The Study of Turnover. 1st ed. Ames: Iowa State University Press.

Renggli, S.; Ziorjen, K. 2005. Die Mitarbeiterfluktuation Kostet Millionen [žiūrèta 2009-10-24]. Prieiga per internetą: <http:// www.lops.ch/pdf/competence_12_03.pdf $>$.
Stübinger, M. 2003. Sozialmanagement /4/ Personalmanagement. Köln: Fortis-Verl.

Startienè, G.; Remeikienè, R. 2009. The influence of demographic factors on the interaction between entrepreneurship and unemployment, Inzinerine Ekonomika - Engineering Economics (4): 60-70.

Šukys, R; Čyras, P; Jakutis, A.; Stankuvienè, A. 2004. Profesinių ligų bei nelaimingų atsitikimų darbe ekonominès ir socialinès pasekmès, Technological and Economic Development of Economy 10(1): 26-31.

Trevor, C. 2001. Interactions among actual easy-of-movement determinants and job satisfaction in the prediction of voluntary, Academy of Management Journal 44(4): 621-638. doi: $10.2307 / 3069407$

Vandenberghe, C. 1999. Organizational Culture, person-culture fit and turnover, Journal of Organizational Behavior 20: 175-184. doi:10.1002/(SICI)1099-1379(199903)20:2<175:: AID-JOB882>3.0.CO;2-E

Winterton, J. 2004. A conceptual model of labour turnover and retention, Human Resouce Development International 7(3): 371-390. doi:10.1080/1367886042000201967

Žukauskas, P; Vveinhardt, J. 2009. Diagnosis of mobbing as discrimination in employee relations, Inzinerine Ekonomika-Engineering Economics (4): 103-113.

Asta STANKEVIČIENĖ. Doctor of Social Sciences, Associate Professor, Department of Economics and Management of Enterprises, Vilnius Gediminas Technical University. Research interests: personnel management.

Aušra LIUČVAITIENĖ. Doctor of Social Sciences, Associate Professor, Department of Economics and Management of Enterprises, Vilnius Gediminas Technical University. Research interests: personnel management, macroeconomics.

Agnẻ ŠIMELYTĖ. PhD student at Vilnius Gediminas Technical University, Department of Economics and Management of Enterprises. Research interests: personnel management. 